\title{
BRINGING RACIAL JUSTICE TO IMMIGRATION LAW
}

\author{
Kevin R. Johnson
}

\begin{abstract}
From at least as far back as the anti-Chinese laws of the 1800s, immigration has been a place of heated racial contestation in the United States. Although modern immigration laws no longer expressly mention race, their enforcement unmistakably impacts people of color from the developing world. Specifically, the laws, as enacted and applied, limit the immigration of people of color to, and facilitate their removal from, the United States.

Modern immigrant rights activism, which has grown by leaps and bounds in recent years, encountered a powerful counter-response led by none other than President Donald J. Trump. His presidential administration made aggressive immigration enforcement a priority like no other in modern U.S. history. Exemplified by the Administration's heartless separation of Central American families, consequences of the U.S. immigration policies and their enforcement fell primarily on immigrants of color.

As the nation collectively engages in a reckoning with historical racial injustice, it is important to recognize that the movement for justice for noncitizens of color shares important commonalities with the goals of the Black Lives Matter movement. Fundamental to both social movements is the demand for an end to systemic racial discrimination in law enforcement.

Part I of this Essay maps the discriminatory foundations of federal immigration law, the lack of constitutional review, and the enduring fortress built by the courts to shield discrimination against immigrants from judicial review. Part II considers the surprising emergence of a powerful immigrant rights movement — energized, organized, and formidable, yet handicapped by the fact that noncitizens cannot vote-fighting for no less than racial justice. Part III summarizes the emergence of the Trump Administration's staunch resistance to that movement, which stridently sought to maintain and reinforce the racial caste quality of the contemporary immigration system. Part IV considers the uncertain future of the quest to bring racial justice to immigration law and suggests a road to its transformation.
\end{abstract}

AUTHOR-Dean and Mabie-Apallas Professor of Public Interest Law and Chicanx Studies, University of California, Davis, School of Law. Thanks to 
the organizers, especially Guy-Uriel Charles, for putting together an amazingly rich collection of racial justice essays and inviting me to contribute. Jack Chin provided helpful comments on a draft of this Essay. I also benefited from comments at the virtual Reckoning and Reform Journal Symposium in December 2020, especially from commentators Aziza Ahmed and Osmundia James and participant Bijal Shah. Law student Joana Peraza Lizarraga, a future lawyer and immigrant rights activist, provided excellent research assistance for this Essay. In April 2021, I virtually presented parts of this Essay in the Jerome Hall Lecture at the University of Indiana Maurer School of Law and benefited from the comments of faculty (especially Luis Fuentes-Rohwer and Christiana Ochoa), staff, and students.

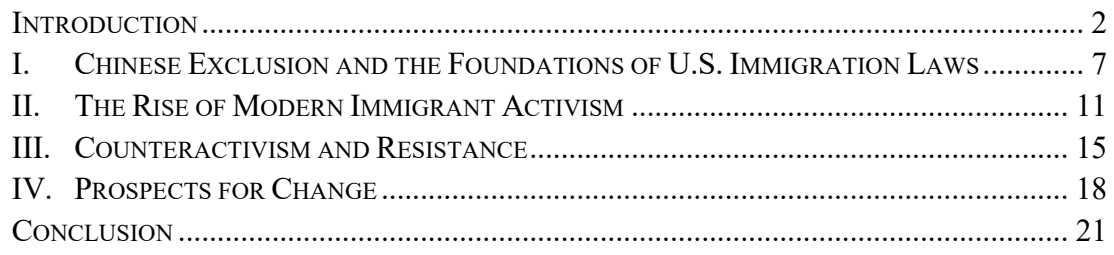

\section{INTRODUCTION}

We live in the midst of an extraordinary combination of social tensions with few, if any, parallels in modern U.S. history. With the death toll mounting daily, the COVID-19 pandemic brought the world to its knees. Widespread pandemic-induced uncertainty, anxiety, economic turmoil, and stress gripped the nation. Moreover, a series of police killings of African Americans in 2020 provoked potent demands for racial justice, demands that many Americans believe were long overdue.

The criminal justice system is frequently condemned as the centerpiece of contemporary systemic racism. For example, in her celebrated book The New Jim Crow, Michelle Alexander contends that, although the Supreme Court outlawed de jure racial segregation, the criminal justice system facilitates systemic discrimination against African Americans under color of law. ${ }^{1}$ In response to the latest string of Black deaths at the hands of police,

\footnotetext{
${ }^{1}$ See generally Michelle AleXAnder, The New Jim CROW: MASS InCARCERATION IN THE AgE OF COLORBLINDNESS (10th anniversary ed. 2020) (analyzing the discriminatory roots of the contemporary criminal justice system and its disparate impacts on African Americans). Examples abound of Supreme Court decisions that commentators, including Alexander, have criticized for allowing racial discrimination to flourish in the criminal justice system. See, e.g., Whren v. United States, 517 U.S. 806, 813 (1996) (holding that, in assessing the legality of police decisions to stop suspects under the Fourth Amendment, courts should not consider officers' subjective racial motivations); United States v. Armstrong, 517 U.S. 456, 469-70 (1996) (rejecting claim of racial bias in crack cocaine prosecutions
} 
protesters and, at times, rioters took to the streets in cities across the country. ${ }^{2}$ Counter-protesters, including armed white supremacists, added to the turmoil. ${ }^{3}$ President Trump pledged to restore law and order, a well-worn code for the use of force to suppress demands for racial justice. ${ }^{4}$ He took the extraordinary step of deploying Department of Homeland Security (DHS) officers, who primarily enforce immigration laws, to disperse protesters in the streets of Portland, Oregon with tear gas and projectiles. ${ }^{5}$ Matters worsened in January 2021 when racial extremists stormed the U.S. Capitol in what some observers characterized as an attempted coup d'état. ${ }^{6}$

As exemplified by the Black Lives Matter movement, a loosely affiliated group behind many of the protests, political activists are challenging the racial hegemony of U.S. society. ${ }^{7}$ This Essay analyzes a similar area of law enforcement that is also experiencing increased demands by activists for racial justice. The fight for immigrant rights, with racial justice at its core, has emerged as one of the most vibrant - and surprising social movements of the new millennium. ${ }^{8}$ Even though today's immigration laws on their face appear neutral with respect to race, their enforcementsimilar to the enforcement of criminal law-has unmistakable and

based on the Equal Protection Clause despite overwhelming statistical evidence); McCleskey v. Kemp, 481 U.S. 279, 319 (1987) (holding that a constitutional challenge to the imposition of death penalty on a Black defendant failed despite statistical evidence demonstrating the impacts of race on death penalty cases).

2 See Jocelyn Grzeszczak, Trump Campaign Ad Uses Image of George Floyd Mourners to Tell Voters 'Stop Joe Biden and His Rioters, ' NEwswEEK (Sept. 10, 2020, 1:26 PM), https://www.newsweek.com/ trump-campaign-ad-uses-image-george-floyd-mourners-tell-voters-stop-joe-biden-his-rioters-1531084 [https://perma.cc/E263-D5TH].

3 See Ryan Devereaux, Leaked Documents Show Police Knew Far-Right Extremists Were the Real Threat at Protests, Not “Antifa," INTERCEPT (July 15, 2020, 12:15 PM), https://theintercept.com/ 2020/07/15/george-floyd-protests-police-far-right-antifa/ [https://perma.cc/BJ49-CGXJ].

4 See Gregory Krieg, Dan Merica \& Ryan Nobles, Why Trump's 'Law and Order' Rhetoric May Not Be as Effective as It Was for Nixon and Reagan, CNN (June 4, 2020, 12:38 PM), https://www.cnn.com/ 2020/06/04/politics/law-and-order-trump-2020/index.html [https://perma.cc/5RMJ-329H].

5 See Associated Press, Portland Protest Groups Sue U.S. over Tear Gas, Rubber Bullets, POLITICO (July 28, 2020, 3:20 PM), https://www.politico.com/news/2020/07/28/portland-protest-groups-sue-teargas-rubber-bullets-384758 [https://perma.cc/G4DJ-XFVN].

${ }^{6}$ See Stephanie K. Baer, Trump Supporters Who Attempted the Coup at the US Capitol Flaunted Racist and Hateful Symbols, BuzzFEED NEws, (Jan. 7, 2021, 1:34 PM), https://www.buzzfeednews. com/article/skbaer/trump-supporters-racist-symbols-capitol-assault [https://perma.cc/S74U-P9EY].

7 See Nicole Chavez, 2020: The Year America Confronted Racism, CNN (2020), https://www.cnn. com/interactive/2020/12/us/america-racism-2020/ [https://perma.cc/N639-8R54]. The contemporary racial reckoning goes far beyond criminal law enforcement. See, e.g., Derrick Bryson Taylor, Confederate Statue near Site of White Nationalist Rally in Charlottesville Is Removed, N.Y. TIMES (Sept. 12, 2020), https://www.nytimes.com/2020/09/12/us/charlottesville-confederate-statue-at-ready.html

[https://perma.cc/7C4Y-YPHP]; Jill Cowan, Berkeley Law School Drops Boalt Name over Racist Legacy, N.Y TIMES (Jan. 30, 2020), https://www.nytimes.com/2020/01/30/us/berkeley-boalt-hall-namechange.html [https://perma.cc/S4NP-UE4Z].

8 See infra Part II. 
disproportionate adverse impacts on people of color from the developing world. ${ }^{9}$ Most fundamentally, the laws, as applied, limit the immigration of people of color to, and facilitate their removal from, the United States. ${ }^{10}$ This is nothing new. From as far back as the anti-Chinese laws of the $1800 \mathrm{~s}$, immigration has been ground zero of vigorous racial contestation in the United States. ${ }^{11}$

Although undocumented immigrants once lived in the "shadows" of American social life seeking to avoid federal immigration enforcement efforts, ${ }^{12}$ many of today's undocumented immigrants, as well as lawful immigrants and their supporters, are publicly demanding justice for immigrants. For some, their ambitious demands include the call to "Abolish ICE," which is more far-reaching and ambitious than the more modest demand to "reform ICE." 13 At its core, through literally advocating for the dismantling of a federal agency that disproportionately interacts with and deports people of color, the Abolish ICE movement demands the just treatment of noncitizens of color.

Immigrant rights activism generated a powerful counter-response led by none other than President Donald J. Trump, whose Administration made aggressive immigration enforcement a priority like no other in modern U.S. history. ${ }^{14} \mathrm{He}$ appealed to a base of supporters demanding severe restrictions on immigration and the mass expulsion of immigrants of color from the country; that same base opposes the Black Lives Matter movement, strongly suggesting that race - and white supremacy - is an overarching goal of their immigration aims. ${ }^{15}$ The strong claims of racism are more than justified. President Trump, for example, portrayed Muslims as presumed terrorists who should be subject to "extreme vetting" before entering the country, if

\footnotetext{
${ }^{9}$ See generally Kevin R. Johnson, Race, the Immigration Laws, and Domestic Race Relations: A "Magic Mirror" into the Heart of Darkness, 73 IND. L.J. 1111 (1998) (analyzing the influence of racism on the immigration laws throughout U.S. history).

${ }^{10}$ See id. at 1131-53.

${ }^{11}$ See generally ERIKA LEE, AMERICA FOR AMERICANS: A HISTORY OF XENOPHOBIA IN THE UNITED STATES (2019) (analyzing the periodic outbursts of xenophobia, including many racial in nature, in U.S. history).

${ }^{12}$ See Presidential Address to the Nation on Immigration Reform, 42 WEEKLY COMP. PRES. Doc. 931 (May 15, 2006) (observing that undocumented "immigrants live in the shadows of our society").

${ }^{13}$ See infra notes 64-65 and accompanying text.

${ }^{14}$ See Anil Kalhan, Revisiting the 1996 Experiment in Comprehensive Immigration Severity in the Age of Trump, 9 DreXel L. Rev. 261, 262 (2017). See generally AdAM B. Cox \& CRistina M. RODRÍGUEZ, THE PRESIDENT AND IMMIGRATION LAW (2020) (chronicling the growth in the immigration powers of the President).

${ }^{15}$ See Sean Collins, Trump Once Flirted with White Nationalism. Now It's a Centerpiece of His White House, Vox (July 21, 2020, 7:50 AM), https://www.vox.com/21313021/trump-white-nationalismsupremacy-miller-bannon-immigration [https://perma.cc/WCB4-MUE8] (analyzing the anti-immigrant and anti-Black foundations of the white nationalist movement that supports President Trump).
} 
not outright banned from doing so. ${ }^{16} \mathrm{He}$ mercilessly attacked Mexican immigrants in racist terms ${ }^{17}$ : indeed, "Trump kicked off his presidential bid ... with harsh words for [Mexican immigrants]... . 'They're bringing drugs. They're bringing crime. They're rapists. And some, I assume, are good people." "'18 "Trump specifically questioned why the U.S. would want to admit more people from Haiti... . [H]e asked why more people from 'shithole countries' should be allowed into the U.S. ... The president suggested that instead, the U.S. should allow more entrants from countries like Norway." 19 Consistent with those statements, the Trump Administration pursued a staggering array of immigration policy initiatives with racially disparate impacts, including, but not limited to, the Muslim ban, the infamous policy of separating migrant children from their parents, and the "Remain in Mexico" policy (both of which applied almost exclusively to Central Americans), ${ }^{20}$ immigration raids, mass detention and removals, eliminating policies providing relief to noncitizens brought to the United States as children, and reducing legal immigration through virtually whatever means necessary. ${ }^{21}$ Undaunted and unapologetic, the Trump Administration day in and day out announced tough new immigration measures that invariably injured noncitizens of color. ${ }^{22}$

\footnotetext{
${ }^{16}$ See Trump v. Hawaii, 138 S. Ct. 2392, 2433, 2436, 2438 (2018) (Sotomayor, J., dissenting) (“[A] reasonable observer would conclude that the [travel ban] was driven primarily by anti-Muslim animus, rather than by the Government's asserted national-security justifications.").

17 See 'Drug Dealers, Criminals, Rapists': What Trump Thinks of Mexicans, BBC News (Aug. 31, 2016), https://www.bbc.com/news/av/world-us-canada-37230916 [https://perma.cc/XPG8-ZVEE].

${ }^{18}$ Katie Reilly, Here Are All the Times Donald Trump Insulted Mexico, TimE (Aug. 31, 2016, 11:35 AM), https://time.com/4473972/donald-trump-mexico-meeting-insult/ [https://perma.cc/65ES-SDNE].

19 Alan Fram \& Jonathan Lemire, Trump: Why Allow Immigrants from 'Shithole Countries'?, Associated PRESS (Jan. 11, 2018), https://apnews.com/article/fdda2ffob877416c8ae1c1a77a3cc425 [https://perma.cc/EWB9-XSB6].

${ }^{20}$ See Innovation L. Lab v. Wolf, 951 F.3d 1073, 1077 (9th Cir. 2020), stay granted, 140 S. Ct. 1564, cert. granted, 141 S. Ct. 617 (2020). Because the Biden Administration changed the policy, the Supreme Court granted a request to remove the case challenging the Remain in Mexico policy from its oral argument calendar. See Ian Millhiser, Two Major Supreme Court Immigration Cases Just Went up in Smoke, Vox (Feb. 3, 2021, 1:10 PM), https://www.vox.com/2021/2/3/22264190/supreme-courtimmigration-border-wall-remain-in-mexico-trump-biden-sierra-club-innovation-law-lab [https://perma.cc/UCU7-DH9A].

${ }^{21}$ See Muzaffar Chishti \& Jessica Bolter, The "Trump Effect" on Legal Immigration Levels: More Perception than Reality?, MigRATION POL'Y INST. (Nov. 20, 2020), https://www.migrationpolicy.org/ article/trump-effect-immigration-reality [https://perma.cc/F9AU-CCNZ].

${ }^{22}$ See Amanda Frost, Alienating Citizens, 114 Nw. U. L. REV. ONLINE 48, 51 (2019), reprinted in 114 Nw. U. L. REV. 241, 244 (2019) (“[T]he Trump Administration's approach to immigration generally. ... has embraced a policy known as 'attrition through enforcement,' under which immigration policies are designed to encourage immigrants to self-deport and discourage would-be immigrants from coming to the United States.").
} 
Because the immigration laws designate who may come and remain in the United States as well as who may be removed, they historically have served as a ready and efficient tool for racial discrimination. ${ }^{23}$ The Trump Administration's separation of families, ${ }^{24}$ which fell almost exclusively on Mexicans and Central Americans, typifies how race has been central to contemporary U.S. immigration policies and their enforcement. Unlike yesterday's nativists, most policymakers today deny that the policies are racially motivated. Although the laws on the books are for the most part racially neutral and color-blind, ${ }^{25}$ the words and deeds of President Trump in combination left little doubt about the centrality of race to his Administration's policy choices. ${ }^{26}$

Immigrants' demands for racial justice share important commonalities with the racial justice goals of the Black Lives Matter movement. Both demand an end to systemic racialized law enforcement and color-blind forms of racial discrimination. With respect to immigration enforcement, noncitizens arrested for minor as well as serious crimes are regularly turned over by state and local law enforcement agencies to federal immigration enforcement authorities for possible removal from the United States. ${ }^{27}$ Because of racially skewed criminal law enforcement, ${ }^{28}$ the overwhelming majority of the noncitizens removed each year are from Latin America, in much larger percentages than their composition of the overall immigrant

${ }^{23}$ See generally Kevin R. Johnson, The "Huddled Masses" Myth: IMmigration ANd CiviL RIGHTS (2004) (analyzing the history of discrimination against various racial and other groups in the U.S. immigration laws).

${ }^{24}$ See Carrie F. Cordero, Heidi Li Feldman \& Chimène I. Keitner, The Law Against Family Separation, 51 Colum. Hum. RTS. L. REV. 430, 435-36 (2020). See generally Mariela Olivares, The Rise of Zero Tolerance and the Demise of Family, 36 GA. ST. U. L. REV. 287 (2020) (reviewing the Trump Administration's use of family separation as a tool of U.S. immigration enforcement).

${ }^{25}$ See Kevin R. Johnson, A Case Study of Color-Blindness: The Racially Disparate Impacts of Arizona's S.B. 1070 and the Failure of Comprehensive Immigration Reform, 2 U.C. IRVINE L. REV. 313, 315 (2010).

${ }^{26}$ See generally Rose Cuison Villazor \& Kevin R. Johnson, The Trump Administration and the War on Immigration Diversity, 54 WAKE FOREST L. REV. 575 (2019) (examining the racial impacts of the Trump Administration's immigration policies).

${ }^{27}$ See Bill Ong Hing, Entering the Trump ICE Age: Contextualizing the New Immigration Enforcement Regime, 5 TEX. A\&M L. REV. 253, 290 (2018).

${ }^{28}$ See, e.g., United States v. Brignoni-Ponce, 422 U.S. 873, 886-87 (1975) (holding that the Border Patrol could consider "Mexican appearance" as one factor in an immigration stop consistent with the Fourth Amendment). See generally Kevin R. Johnson, How Racial Profiling in America Became the Law of the Land: United States v. Brignoni-Ponce and Whren v. United States and the Need for Truly Rebellious Lawyering, 98 GEO. L.J. 1005, 1045-73 (2010) (analyzing the Supreme Court decisions encouraging racial profiling in law enforcement). 
population. ${ }^{29}$ The disparate impacts are not lost on the advocates of the removal of "criminal aliens" 30 or the greater Latinx community, with citizens as well as noncitizens living in daily fear of immigration enforcement.

In helping us analyze the battle over racial justice for immigrants in the contemporary United States, Part I of this Essay maps the discriminatory foundations of immigration law, the continuing lack of meaningful constitutional review of the laws, and the enduring, often impenetrable, immunity from constitutional protections built by the courts to shield invidious discrimination from judicial review. Part II considers the surprising emergence of a formidable immigrant rights movementenergized and organized yet handicapped by the fact that noncitizens cannot vote-fighting for no less than racial justice for noncitizens. Part III summarizes the emergence of the Trump Administration's vigorous opposition to that movement, which fundamentally sought to maintain and reinforce the racial caste quality of the contemporary immigration system. Part IV considers the uncertain future of the quest to bring racial justice to immigration law. It contends that, although immigration activism is essential for truly transformative immigration reform, a full transformation can be accomplished only if the Supreme Court requires meaningful constitutional review of the immigration laws and allows the courts to serve as a true check on racial animus.

\section{CHINESE EXCLUSION AND THE FOUNDATIONS OF U.S. IMMIGRATION LAWS}

In the 1800s, widespread state and local attacks on Chinese immigrants by an organized white populist movement pushed Congress to pass the nation's first comprehensive immigration laws, which were ignominiously known as the Chinese Exclusion Laws. ${ }^{31}$ In The Chinese Exclusion Case, ${ }^{32}$ the Supreme Court upheld the first of the series of laws, the Chinese

29 See Yolanda Vázquez, Constructing Crimmigration: Latino Subordination in a "Post-Racial" World, 76 Оніо Sт. L.J. 599, 654 (2015); see also Alina Das, Inclusive Immigrant Justice: Racial Animus and the Origins of Crime-Based Deportation, 52 U.C. DAVIS L. REV. 171, 176 (2018) ("By examining the origins of crime-based deportation, we begin to see that the racialized outcomes of the modern-day system are no accident of history. Nor is the targeting of immigrants with criminal records an inevitable aspect of immigration regulation.").

${ }^{30}$ See Elise Foley, Trump Refers to Immigrants as 'Animals.' Again., HufFPost (May 16, 2018, 6:55 PM), https://www.huffpost.com/entry/trump-calls-immigrants-animals-again_n_5afca15fe4b07793 45d59e2a [https://perma.cc/B64T-STF9].

${ }^{31}$ See generally Beth Lew-Williams, The Chinese Must Go: Violence, EXClusion, AND the MAKING OF THE ALIEN IN AMERICA (2018) (chronicling the virulent anti-Chinese movement of the 1800s in the United States).

32 Ping v. United States (The Chinese Exclusion Case), 130 U.S. 581, 606 (1889). 
Exclusion Act of $1882,{ }^{33}$ which outlawed the immigration of workers from China to the United States. Giving birth to the so-called plenary power doctrine, the Court unequivocally proclaimed that if Congress "considers the presence of foreigners of a different race in this country, who will not assimilate with us, to be dangerous to its peace and security,... its determination is conclusive upon the judiciary." ${ }^{34}$ The Court made it clear that Chinese immigrants simply had no claim to equal protection of law that the courts would enforce. ${ }^{35}$ This ruling became foundational precedent for judicial deference to the legislative and executive branches' plenaryunfettered-power over immigration..$^{36}$ To this day, the Supreme Court has not overruled The Chinese Exclusion Case. ${ }^{37}$

Immigration laws define whom to exclude and deport from the United States. Discrimination is necessary for the law to accomplish that mission. The Chinese Exclusion Case allowed Congress to discriminate without fear of judicial interference. Immigrants in effect are subject to what philosophers understand to be "the State of Nature," with the politically powerful dominating the weak. ${ }^{38}$ Full-blown constitutional immunity for the immigration laws - the State of Nature - allows Congress to act on its worst instincts, which is precisely what has occurred at various times through to the present.

Unsurprisingly, political resistance to the efforts at Chinese exclusion failed in the late $1800 \mathrm{~s}^{39}$ Unable to vote and lacking meaningful representation in government, Chinese immigrants lacked the political power to mount successful resistance to rampant anti-Chinese sentiment. Allowing politics to run their course generally meant that the laws punished Chinese

\footnotetext{
${ }^{33}$ Chinese Exclusion Act, Pub. L. No. 47-126, 22 Stat. 58 (1882); see also Raquel E. Aldana \& Thomas O'Donnell, A Look Back at the Warren Court's Due Process Revolution Through the Lens of Immigrants, 51 U. PAC. L. REV. 633, 639 (2020) (footnote omitted) ("Legal scholars and historians ... recognize the Chinese Exclusion Act of 1882 as the turning point in American immigration history ....").

${ }^{34}$ The Chinese Exclusion Case, 130 U.S. at 606 (emphasis added).

${ }^{35}$ Although denying constitutional review of federal immigration laws, the Supreme Court subjects alienage classifications in state laws to Equal Protection review. See Brian Soucek, The Return of Noncongruent Equal Protection, 83 FORDHAM L. REV. 155, 173-86 (2014).

${ }^{36}$ See id. at $173-74$.

${ }^{37}$ See Gabriel J. Chin, Segregation's Last Stronghold: Race Discrimination and the Constitutional Law of Immigration, 46 UCLA L. REv. 1, 3-11 (1998); see, e.g., Fiallo v. Bell, 430 U.S. 787, 792 (1977) (citing The Chinese Exclusion Case); Kleindienst v. Mandel, 408 U.S. 753, 765-66 (1972) (citing The Chinese Exclusion Case); Zadvydas v. Davis, 533 U.S. 678, 703 (2001) (Scalia, J., dissenting) (same).

${ }^{38}$ See George A. Martinez, Race, American Law and the State of Nature, 112 W. VA. L. REV. 799, 811-12 (2010) (analyzing the plenary power doctrine through the philosophical concept of the State of Nature).

39 See generally Charles J. McClain, In SEARCh of Equality: The ChineSe Struggle Against DisCRIMINATION IN NINETEENTH-CENTURY AMERICA (1994) (documenting Chinese resistance to discrimination in the $1800 \mathrm{~s}$ ).
} 
immigrants with impunity. Legal challenges had limited impacts moderating the laws and their enforcement. ${ }^{40}$ Unchecked racism meant that the laws were enforced to the detriment of Chinese immigrants.

Similar to Jim Crow's subordination of African Americans, ${ }^{41}$ The Chinese Exclusion Case's failure to subject the immigration laws to constitutional review made discrimination against the Chinese entirely lawful. To exacerbate matters, by decreeing that the immigration laws were immune from constitutional review, the Supreme Court signaled to Congress that it could pass laws that punished various unpopular groups of immigrants throughout the twentieth century. ${ }^{42}$ Subsequent laws restricted immigration to the United States not only from China but all of Asia and southern and eastern Europe, with their inferior "races" of people. ${ }^{43}$

Indeed, the Supreme Court's hands-off approach to the review of the immigration laws made it possible for Congress and the President to transition between which races the laws targeted for discrimination. As we have seen, Chinese immigrants were the popular focus of attack in the late 1800 s, with virulent animosity that some might find difficult to fathom today. Latinx and Muslim noncitizens are the contemporary disfavored racial groups, with Asians often unpopular as well (as demonstrated by the antiAsian hate crimes that escalated with the global pandemic). ${ }^{44}$ Those groups have been the subjects of a full array of immigration policies and procedures. ${ }^{45}$ For example, with the Supreme Court's deference to the Executive Branch, President Trump's travel ban on the admission of

40 See, e.g., Yick Wo v. Hopkins, 118 U.S. 356, 374 (1886) (finding unconstitutional a San Francisco ordinance enforced primarily against Chinese laundries).

41 See, e.g., Plessy v. Ferguson, 163 U.S. 537, 552 (1896) (adopting the separate but equal doctrine to reject constitutional challenges to the segregation of African Americans), overruled by Brown v. Bd. of Educ., 347 U.S. 483, 495 (1954). In his famous dissent in Plessy, Justice Harlan proclaimed that "[o]ur constitution is color-blind" but denigrated the Chinese as "a race so different from our own that we do not permit those belonging to it to become citizens of the United States. Persons belonging to it are, with few exceptions, absolutely excluded from our country." 163 U.S. at 559, 561 (Harlan, J., dissenting).

42 See JOHNSON, supra note 23 (citing authority).

43 See generally JoHn Higham, StRAngers in THE LAND: PATTERnS OF AmERICAN NATIVISM, 1860-1925 (4th ed. 2002) (documenting nativism culminating in congressional passage of the national origins quota system in 1924).

44 See Asian Am. Bar Ass'N OF N.Y., A Rising Tide of HATE And Violence Against Asian AMERICANS IN NEW YORK DURING COVID-19: IMPACT, CAUSES, SOlutions 3-5 (2021), https://cdn.ymaws.com/www.aabany.org/resource/resmgr/press_releases/2021/A_Rising_Tide_of_Hate _and_Vi.pdf [https://perma.cc/RV46-7CMZ].

$4 \overline{5}$ See, e.g., supra text accompanying notes 20-22 (reviewing the Trump Administration immigration policies and their impacts on immigrants of color). 
noncitizens from a group of predominantly Muslim nations, and many other immigration initiatives, fit comfortably into this discriminatory history. ${ }^{46}$

Although the Supreme Court in some cases has grudgingly allowed limited review of immigration laws and policies, ${ }^{47}$ the default rule under The Chinese Exclusion Case and its progeny, which courts continue to rely upon, ${ }^{48}$ is that there is no constitutional review of many immigration decisions. Contemporary examples include the travel ban case and the 2020 decision upholding the removal without a hearing of an asylum seeker apprehended in the United States. ${ }^{49}$ Importantly, the Supreme Court has never overruled The Chinese Exclusion Case. ${ }^{50}$ Indeed, at the same time that the Court famously ended de jure racial segregation against African Americans in $1954,{ }^{51}$ it unabashedly reaffirmed the plenary power doctrine..$^{52}$ The doctrine remains in place despite the incredibly weighty individual rights at stake when a noncitizen seeks admission into the United States (for example, to join family or for employment) or faces removal from the country and possibly "the loss 'of all that makes life worth living." ${ }_{53}$ Immigrants subject to removal face separation from family, friends, community, jobs, and their entire lives in the United States. Consistent with

46 See Trump v. Hawaii, 138 S. Ct. 2392, 2403 (2018). For criticism of the Supreme Court's upholding of the travel ban, see Robert S. Chang, Whitewashing Precedent: From the Chinese Exclusion Case to Korematsu to the Muslim Travel Ban Cases, 68 CASE W. RSRV. L. ReV. 1183, 1184-87 (2018); Jill E. Family, The Executive Power of Political Emergency: The Travel Ban, 87 UMKC L. REv. 611, 624-27 (2019); Shoba Sivaprasad Wadhia, National Security, Immigration and the Muslim Bans, 75 WASH. \& LEE L. REV. 1475, 1488-1500 (2018).

47 See Kleindienst v. Mandel, 408 U.S. 753, 770 (1972) (finding that the U.S. government had offered "a facially legitimate and bona fide reason" for a visa denial).

${ }^{48}$ See supra note 37 (citing cases).

${ }^{49}$ See, e.g., Dep't of Homeland Sec. v. Thuraissigiam, 140 S. Ct. 1959, 1981-83 (2020) (rejecting due process challenges to expedited removal); Trump, 138 S. Ct. at 2418-20 (upholding Trump's Muslim ban on national security grounds); see also Sale v. Haitian Ctrs. Council, Inc., 509 U.S. 155, 188 (1993) (citation omitted) (refusing to disturb the Haitian interdiction policy and affording it deference because such decisions implicate "foreign and military affairs for which the President has unique responsibility"). In a few contemporary instances, the Supreme Court, without mentioning the plenary power doctrine, has invalidated provisions of the immigration laws on constitutional grounds. See Sessions v. Dimaya, $138 \mathrm{~S}$. Ct. 1204, 1210 (2018); Sessions v. Morales-Santana, 137 S. Ct. 1678, 1686 (2017); see also Graham v. Richardson, 403 U.S. 365, 376 (1971) (striking down a state law barring public benefits receipt by lawful immigrants).

${ }^{50}$ See Chin, supra note 37 , at 3-11.

51 See Brown v. Bd. of Educ., 347 U.S. 483, 493-94 (1954).

52 See Galvan v. Press, 347 U.S. 522, 531 (1954) (citation omitted) (allowing the deportation of a Mexican immigrant for Communist Party membership because "there is not merely 'a page of history' ... but a whole volume" of cases limiting judicial review of the immigration laws); Harisiades v. Shaughnessy, 342 U.S. 580, 597 (1952) (Frankfurter, J., concurring) (“[W]hether immigration laws have been crude and cruel, whether they may have reflected xenophobia in general or anti-Semitism or antiCatholicism, the responsibility belongs to Congress.").

${ }^{53}$ Bridges v. Wixon, 326 U.S. 135, 147 (1945) (citation omitted). 
the plenary power tradition, Congress has by statute barred judicial review of many Executive Branch immigration decisions. ${ }^{54}$ In stark contrast, when individual rights of U.S. citizens are implicated, modern constitutional law generally requires meaningful judicial review of the constitutionality of the law and its implementing policies. ${ }^{55}$

Because of the plenary power doctrine, it was not the courts but the political process that removed the blatant racism from U.S. immigration laws. The Civil Rights Movement, combined with the stark inconsistency of racially discriminatory immigration laws with modern civil rights sensibilities, culminated in the passage of the Immigration and Naturalization Act of 1965. ${ }^{56}$ That law formally barred discrimination in immigrant admissions.$^{57}$ At the same time, however, Congress put into place limitations on immigration from any single nation - known as per-country ceilings - that limit Latinx immigration to this day and transformed many future legal Latinx immigrants into undocumented ones. ${ }^{58}$

\section{THE RISE OF MODERN IMMIGRANT ACTIVISM}

Unlike the past, the twenty-first century has seen the rapid growth of an organized and increasingly powerful immigrant rights movement. As will be discussed, that movement's efforts were historically directed at the courts. But an inability to make progress through the judiciary, combined with changing demographics and political sensibilities, has inspired immigrant rights activists to move their fight to the political arena. No longer confined to the shadows of U.S. social life, immigrants, documented and not, are now front and center of protests and political movements demanding change. ${ }^{59}$

\footnotetext{
${ }^{54}$ See generally Lenni B. Benson, Back to the Future: Congress Attacks the Right to Judicial Review of Immigration Proceedings, 29 CONN. L. REV. 1411 (1997) (reviewing the many restrictions on judicial review in 1996 immigration reforms).

55 See, e.g., Janus v. Am. Fed'n of State, Cnty., \& Mun. Emps., Council 31, 138 S. Ct. 2448, 2486 (2018) (invalidating a statute on First Amendment grounds); District of Columbia v. Heller, 554 U.S. 570, 635 (2008) (holding that a handgun ban violated the Second Amendment).

${ }^{56}$ Immigration and Naturalization Act, Pub. L. No. 89-236, 79 Stat. 911 (1965).

57 See 8 U.S.C. $§ 1152(a)(1)(A)$ ("[N]o person shall receive any preference or priority or be discriminated against in the issuance of an immigrant visa because of the person's race, sex, nationality, place of birth, or place of residence.").

${ }^{58}$ See Kevin R. Johnson, The Beginning of the End: The Immigration Act of 1965 and the Emergence of the Modern U.S.-Mexico Border State, in ThE ImMigration AND NATIONALiTy ACT OF 1965: Legislating A New America 116, 120 (Gabriel J. Chin \& Rose Cuison Villazor eds., 2015).

${ }^{59}$ See Kathryn Abrams, Contentious Citizenship: Undocumented Activism in the Not1More Deportation Campaign, 26 BERKELEY LA RAZA L.J. 46, 47 (2016) (analyzing an ICE protest "exemplif[ying] a new phase of undocumented activism"); Susan Bibler Coutin, 'Otro Mundo Es Posible': Tempering the Power of Immigration Law Through Activism, Advocacy, and Action, 67 BuFF. L. REV. 653, 664 (2019) ("Through community resistance, immigrants develop means of persisting in the
} 
They call not just for piecemeal reform of the immigration laws but also for no less than recognition of the rights of, and full justice for, immigrants, including immigrants of color.

The fact that immigrants cannot directly exercise political power through voting historically meant that they found it necessary to resort to the courts in the quest for justice. However, the restrictions on constitutional review thwarted - and continue to thwart-efforts to secure meaningful change through litigation. Although at times ensuring adherence to the law, litigation rarely protects immigrants from unfair and punitive laws. Courts obviously cannot write, or rewrite, legislation. Rather, positive improvements in the laws for immigrants can only be achieved through Congress changing the immigration laws. To secure congressional action, those seeking to bring about change must advocate through protests, coordinating political activism with immigrant and civil rights groups, and appealing to the hearts and minds of voters. ${ }^{60}$

A powerful immigrant rights movement only became viable in the last fifty years. As we have seen, due to their widespread unpopularity among the general public and the lack of meaningful representation in Congress, Chinese immigrants resorted to the courts for protection in the 1800s when faced with laws discriminating against them. ${ }^{61}$ Successful political action opposing punitive immigration measures was simply not a realistic possibility at that time for Chinese immigrants. Similarly, immigrant and civil rights organizations lacked the necessary political power to muster much opposition to, for example, the repatriation of persons of Mexican ancestry during the Great Depression, the internment of persons of Japanese ancestry (including U.S. citizens) during World War II, mass removals of Mexican immigrants in Operation Wetback in 1954, and many similar discriminatory milestones of U.S. history. ${ }^{62}$

The rapid and dramatic growth in the Latinx population has contributed to the growth of immigrant political power. With an extremely limited role for the judiciary to review immigration policy choices of Congress and the

\footnotetext{
United States in defiance of exclusionary measures.”). See generally WALTER J. NichOLLS, ThE IMMigRANT Rights MOVEMENT: THE BATtLE OVER NATIONAL Citizenship (2019) (recounting the emergence of the grass roots immigrant rights movement); LAURA WIDES-MUÑOZ, THE MAKING OF A

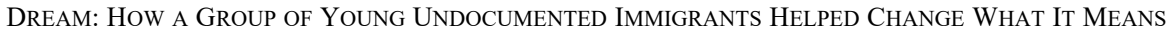
TO BE AMERICAN (2018) (explaining how undocumented college students sparked a powerful immigrant rights movement).

${ }^{60}$ See supra note 59 (citing authorities).

61 See supra Part I.

${ }^{62}$ See Kevin R. Johnson, Trump's Latinx Repatriation, 66 UCLA L. REV. 1444, 1446, 1453-67 (2019); see also Leticia M. Saucedo, Mexicans, Immigrants, Cultural Narratives, and National Origin, 44 ARIZ. ST. L.J. 305, 307 (2012) (explaining that "immigration status is a key and pivotal component of the character of the Mexican worker" that is relied on to justify discrimination.).
} 
Executive Branch, ${ }^{63}$ the political process currently is the most likely way to secure lasting and meaningful change in the immigration laws and their administration and enforcement. Today, unlike the Chinese immigrants fighting the Chinese Exclusion Act, the immigrant rights and Black Lives Matter movements understand political action, not the courts, as the road to meaningful change. Risking their own lives and liberty through protest, activists seek to force law enforcement to treat immigrants and African Americans with humanity and respect.

And they are doing just that-immigrants today are literally taking to the streets in protests. Despite their inability to make themselves directly heard through the ballot box, immigrants and their supporters have organized a robust and powerful political movement. Embraced wholeheartedly by some mainstream political leaders, ${ }^{64}$ their demands go so far as to include a call for the abolition of ICE, the primary arm of immigration enforcement of the U.S. government. ${ }^{65}$

Put differently, similar to civil rights activists of the 1950s and 1960s, ${ }^{66}$ undocumented immigrants and other immigrant activists today are at the center of political activity. It is difficult to pinpoint the precise time, but immigrant activism increased as versions of the DREAM Act, which would create a path to legalization for undocumented youth, were introduced in Congress over the last twenty years. ${ }^{67}$ For instance, a punitive immigration bill passed by the U.S. House of Representatives triggered protests of tens of thousands of people in cities across the United States in 2006. ${ }^{68}$ The bill "would have made the mere status of being an undocumented immigrant a felony subject to imprisonment as well as deportation from the United States. Arguably, it also would have imposed criminal sanctions on persons who

63 See supra Part I.

64 See Gregory Krieg, The Movement to 'Abolish ICE' Is Heating up - and Going Mainstream, CNN (July 2, 2018, 11:00 AM), https://www.cnn.com/2018/06/30/politics/abolish-ice-movement-gainingsupport-democrats/index.html [https://perma.cc/UM6G-7RV8].

65 See Peter L. Markowitz, Abolish ICE . . and Then What?, 129 YALE L.J.F. 130, 130-33 (2019).

${ }^{66}$ See, e.g., Fiza Pirani, 'Get in the Way': The Story Behind the John Lewis Monument in Selma, Alabama, AtLANTA J.-Const. (July 30, 2018), https://www.ajc.com/news/local/get-the-way-the-storybehind-the-john-lewis-monument-selma-alabama/X1YmoIQjgDeriTCUb411EL/ [https://perma.cc/458CB7MC] (discussing how the late Congressman John Lewis suffered beatings while participating in peaceful civil rights protests).

67 The latest DREAM Act bill was introduced in 2021. See Hannah Miao, Bipartisan Pair of Senators Reintroduces Immigration Reform Bill Protecting 'Dreamers,' CNBC (Feb. 4, 2021, 10:45 PM), https:/www.cnbc.com/2021/02/04/dream-act-lindsey-graham-dick-durbin-unveil-latest-version-ofimmigration-reform-bill.html [https://perma.cc/HJ7R-8468]. See generally MicHAEL A. OLIVAS, PERChance to DREAM: A Legal AND Political History of THE DREAM ACT \& DACA (2020) (analyzing the movement for passage of the DREAM Act).

${ }^{6}$ See Kevin R. Johnson \& Bill Ong Hing, The Immigrant Rights Marches of 2006 and the Prospects for a New Civil Rights Movement, 42 HARV. C.R.-C.L. L. REV. 99, 100 (2007). 
provided humanitarian assistance to undocumented immigrants." 69 Since the mass protests in 2006, political resistance to harsh immigration policies has become commonplace. The Deferred Action for Childhood Arrivals (DACA) policy ${ }^{70}$ and its extension of limited legal status to hundreds of thousands of young immigrants resulted from the political movement. When President Trump attempted to rescind DACA, beneficiaries of the policy led the potent resistance. ${ }^{71}$ In similar responses to grassroots political pressure, at least one state (California) and numerous cities have declared themselves to be sanctuaries for immigrants and sought to shield them to the extent possible from federal immigration enforcement. ${ }^{72}$

Immigrant activists knowingly take risks beyond those posed to U.S. citizen activists who engage in political action. In fact, the Trump Administration allegedly targeted immigrant protesters, including DACA recipients, for removal. ${ }^{73}$ Undaunted and unafraid, immigrants have moved into the political arena in ways dramatically different than the past.

Immigrant rights and Latinx civil rights organizations today are active politically. Groups, such as the Mexican American Legal Defense \& Education Fund (MALDEF) have grown in political power in recent years. ${ }^{74}$ New grassroots immigrant rights groups have emerged. A growing political bloc, Latinx voters, many of whom take immigration issues seriously, are vigorously courted in elections. ${ }^{75}$ Consequently, political activism prodding government action on immigration is significantly greater today than was the case in the era of Asian exclusion.

\footnotetext{
${ }^{69} \mathrm{Id}$.

70 See Dep't of Homeland Sec. v. Regents of the Univ. of Cal., 140 S. Ct. 1891, 1901-05 (2020).

${ }^{71}$ See Kevin R. Johnson, Lessons About the Future of Immigration Law from the Rise and Fall of DACA, 52 U.C. DAVIS L. REV. 343, 372-73 (2018). See generally Olivas, supra note 67 (analyzing the history of DACA and its legacy).

${ }^{72}$ See Rose Cuison Villazor \& Pratheepan Gulasekaram, Sanctuary Networks, 103 MinN. L. ReV. 1209, 1210-11 (2019).

${ }^{73}$ See Jason A. Cade, Judicial Review of Disproportionate (or Retaliatory) Deportation, 75 WASH. \& LeE L. Rev. 1427, 1430 (2018); Jennifer M. Chacón, Citizenship Matters: Conceptualizing Belonging in an Era of Fragile Inclusions, 52 U.C. DAVIS L. REV. 1, 51 n.180 (2018); see, e.g., Ragbir v. Homan, 923 F.3d 53, 78-79 (2d Cir. 2019) (showing the possibility for retaliatory removal wherein the court entered an injunction in a case in which an activist alleged being targeted for removal because of his criticism of U.S. immigration authorities), vacated sub nom. Pham v. Ragbir, 141 S. Ct. 227 (2020) (remanding for further consideration in light of Dep't of Homeland Sec. v. Thuraissigiam, 140 S. Ct. 1959 (2020)).

${ }^{74}$ See History, MALDEF, https://www.maldef.org/history [https://perma.cc/TWT8-XF5H].

${ }^{75}$ See, e.g., Jacqueline Alemany, Power Up: Biden Faces Challenge with Latino Voters in Florida as Trump Makes Inroads, WASH. POST (Sept. 23, 2020, 5:37 AM), https://www.washingtonpost.com/ politics/2020/09/23/power-up-biden-faces-uphill-challenge-with-latino-voters-florida-trump-makesinroads [https://perma.cc/EJA5-5MTA].
} 
Changing sensibilities about racial discrimination, civil rights, and immigration have influenced the political process. Those changes make it more likely that an organized civil rights movement for immigrants will be part of the nation's political future. ${ }^{76}$ Political action secured some improvements in the contemporary era, with the political pressure culminating in DACA and state and local sanctuary laws serving as prominent examples. ${ }^{77}$

Reflecting the evolving political climate, Congress has debated comprehensive immigration reform for close to two decades. ${ }^{78}$ The rancorous debate will likely continue, with divisive disputes emerging over the appropriate reform. A stalemate between Republicans and Democrats in Congress over reform has defeated - at least for the moment - possibilities for meaningful change through legislation. But the organized and increasingly powerful immigrant rights movement, a necessary ingredient for transformation of the immigration laws, appears here to stay.

\section{COUNTERACTIVISM AND RESISTANCE}

As discussed in Part I, politics, not the courts, ended the era of Chinese exclusion. With limited judicial review of the immigration laws and policies, the courts could not, and still cannot, be relied upon to meaningfully intervene to protect vulnerable immigrants from the excesses of the political process. Although political action is the only available alternative to secure change, the history of immigration politics also tells a cautionary tale about immigration politics. Anti-immigrant forces seeking to punish immigrants regularly crop up in response to new waves of immigrants and periodically dominate the political process. ${ }^{79}$

The passion underlying the Trump immigration revolution may surprise some Americans. However, as we saw with the emergence of the Chinese exclusion laws, anti-immigrant and racist impulses motivating political movements targeting immigrants of color have a long history in the United States. ${ }^{80}$ And the immigration laws, with their immunity from constitutional review, are an ideal place to punish groups disfavored by the majority-or

\footnotetext{
${ }^{76}$ See Johnson \& Hing, supra note 68, at 116-37.

77 See supra text accompanying notes 70-72.

${ }^{78}$ See generally Kevin R. Johnson, Ten Guiding Principles for Truly Comprehensive Immigration Reform: A Blueprint, 55 WAYNE L. REV. 1599 (2009) (analyzing various possibilities for comprehensive immigration reform).

79 See supra text accompanying notes 14-22 (reviewing Trump Administration's immigration enforcement measures and how they appealed to his supporters).

${ }^{80}$ See supra Part I.
} 
at least a dedicated minority—of voters. ${ }^{81}$ Some might have thought that blatant anti-immigrant policy measures were part of U.S. immigration history, rather than its present, and have no place in the twenty-first century. That view, however, is seriously mistaken. From the Chinese exclusion laws in the 1800 s to family separation of Latinx noncitizens in $2019,{ }^{82}$ immigration measures that injure noncitizens of color who cannot adequately defend themselves in the political process have been employed. And it is not exclusively people of color who are adversely affected; the poor, political minorities, persons with disabilities and the infirm, women, gays and lesbians, and other subordinated groups all have been subject to the wrath of the U.S. immigration laws. ${ }^{83}$

Restrictionists criticized the Obama Administration for more moderate immigration policies than those pursued by the Trump Administration; in fact, the Obama Administration's removal of hundreds of thousands of immigrants led to the President being dubbed the "Deporter-in-Chief." ${ }_{44}$ Nonetheless, through its rhetoric and actions, the Trump Administration took immigration enforcement to extraordinary new and, to many, frightening levels. If nothing else, the popularity of President Trump's aggressive immigration agenda demonstrates that some Americans, in fact, ardently favor tough on immigration measures that both directly and indirectly punish immigrants of color. ${ }^{85}$ The enthusiastic chant at Trump rallies during the 2016 campaign to "[b]uild that wall" along the U.S.-Mexico border exemplifies the strength of contemporary anti-immigrant, anti-Mexican sentiment. ${ }^{86}$ These supporters often vigorously endorse the general view that "America First" should serve as the touchstone for the nation's immigration policies. ${ }^{87}$

\footnotetext{
${ }^{81}$ See infra text accompanying notes 82-97.

82 See supra note 24 (citing authorities).

${ }^{83}$ See Johnson, supra note 23 (analyzing the history of discrimination against various disfavored groups in the U.S. immigration laws).

${ }^{84}$ Angélica Cházaro, Challenging the "Criminal Alien" Paradigm, 63 UCLA L. REV. 594, 643 (2016) (observing that the head of the National Council of La Raza referred to President Obama as the "Deporter-in-Chief").

${ }^{85}$ See supra text accompanying notes 14-22.

${ }^{86}$ See Jenna Johnson, 'Build That Wall' Has Taken on a Life of Its Own at Donald Trump's Rallies - but He's Still Serious, WASH. POST (Feb. 12, 2016, 9:36 PM), https://www.washingtonpost.com/news/ post-politics/wp/2016/02/12/build-that-wall-has-taken-on-a-life-of-its-own-at-donald-trumps-ralliesbut-hes-still-serious/ [https://perma.cc/698F-Z5FB].

${ }^{87}$ See Caitlin Oprysko \& Anita Kumar, Trump Pushes Aggressive 'America First' Message to World Leaders, Politico (Sept. 24, 2019, 10:50 AM), https://www.politico.com/story/2019/09/24/trumpamerica-first-unga-1509356 [https://perma.cc/9Z7A-X35H].
} 
Immigration law was an ideal place for President Trump to pursue racial goals while denying that race has anything to do with the policy choices. ${ }^{88}$ The color-blind laws, as applied, disparately impact people of color. With fiery and unabashedly racist rhetoric, President Trump made crystal clear the underlying racial objectives of his tough immigration measures..$^{89}$ Putting his words into action, the Trump Administration engaged in a series of measures that constituted nothing less than a Latinx repatriation similar to others in U.S. history. ${ }^{90}$ After kicking off his successful presidential campaign by bluntly attacking Mexican immigrants as criminals and rapists, ${ }^{91}$ President Trump, among other things, sought to deter asylum seekers - most of whom had fled widespread violence in Central America-from coming to the United States through mass detention, including by separating migrant parents and children; moving to defund so-called sanctuary cities; building a wall along the U.S.-Mexico border; attacking birthright citizenship; challenging family immigration (denigrated by President Trump as "chain migration"); limiting the migration of noncitizens of modest means to the United States; ending DACA; and eliminating Temporary Protected Status (TPS) for Salvadorans, Haitians, and other noncitizens of color. ${ }^{92}$

Given its repeated domination of the national political discourse, one cannot underestimate the resilience of the political forces that supported President Trump's anti-immigrant, anti-minority, and pro-immigrationenforcement agenda. President Trump tapped into the support of a vocal group of U.S. citizens who demand tough immigration measures. That base voices unequivocal support for policies much tougher on immigrants than President Obama's, even though those measures had devastating impacts. ${ }^{93}$

The good news is that in pursuing an "America First" immigration program, the Trump Administration kept immigration in the headlines and at the forefront of the national consciousness. Although overshadowed by the U.S. government's failed response to the global pandemic, immigration was an issue in the 2020 election. ${ }^{94}$ That immigration has been in the national spotlight may ultimately benefit future reform efforts. The 2020 Democratic presidential ticket, for example, pledged to roll back many of the signature

${ }^{88}$ See supra text accompanying notes 14-22.

89 See Cuison Villazor \& Johnson, supra note 26.

90 See Johnson, supra note 62, at 1467.

91 See Reilly, supra note 18 and accompanying text.

92 See generally Cuison Villazor \& Johnson, supra note 26 (reviewing the disparate racial impacts of the Trump Administration's immigration initiatives on noncitizens of color).

93 See supra text accompanying notes 85-87.

94 See supra text accompanying note 75. 
Trump immigration policy initiatives and called for comprehensive immigration reforms..$^{95}$

In thinking about political action to bring racial justice to the immigration laws, one must factor into the equation a likely backlash resisting any proposal that would change the racial status quo. Changing racial demographics and their threat to white supremacy deeply trouble many Americans. ${ }^{96}$ In fact, as the policy measures of the Trump Administration demonstrate, a strong core of support exists for moving away from what are perceived as overly lenient immigration policies. ${ }^{97}$

Progressive change to the immigration laws will require addressing the racial concerns of a committed segment of the U.S. population. Racial animus, although at times muted on the domestic scene, is unleashed when it comes to immigrants of color, with the courts failing to moderate racist impulses. In short, the strength and durability of the anti-immigrant, antiminority sentiment stands as a formidable barrier to change.

\section{PROSPECTS FOR CHANGE}

Comprehensive immigration reform has been discussed for close to two decades. ${ }^{98}$ Although reform measures had gained political traction immediately before September 11, 2001, those efforts stalled with popular worries about national security. ${ }^{99}$ Since then, immigration reform has been vigorously debated. President Obama promised reform, but it did not become one of his legislative priorities until his second term. ${ }^{100}$ His Administration initially ramped up removals with the hope that, by demonstrating a firm commitment to enforcement, Republicans in Congress eventually might come around to support comprehensive immigration reform. ${ }^{101}$ The result was record-setting removals, amounting to about 400,000 a year during

${ }_{95}$ See Adam M. Taylor \& Michael Smallberg, How Biden Might Change Trump's Immigration Policies, WASH. POST (Sept. 25, 2020, 11:35 AM), https://www.washingtonpost.com/business/howbiden-might-change-trumps-immigration-policies/2020/09/24/163099e2-fe 7f-11 ea-b0e4-350e4e60cc9 1_story.html [https://perma.cc/CE4C-U8UP].

${ }^{96}$ See Brian Resnick, White Fear of Demographic Change Is a Powerful Psychological Force, Vox (Jan. 28, 2017, 12:30 PM), https://www.vox.com/science-and-health/2017/1/26/14340542/white-feartrump-psychology-minority-majority [https://perma.cc/GW9P-K7U3].

${ }^{97}$ See supra text accompanying notes 85-93.

${ }_{98}$ See Johnson, supra note 78 and accompanying text.

99 See Kevin R. Johnson \& Bernard Trujillo, Immigration Reform, National Security After September 11, and the Future of North American Integration, 91 MiNN. L. REV. 1369, 1396-99 (2007).

${ }^{100}$ See Richard Cowan \& Julia Edwards, Obama Seeks to Restore Trust with Disappointed Latinos, HUFFPOST (Dec. 2, 2014), https://www.huffpost.com/entry/obama-disappoints-latinos_n_5919284 [https://perma.cc/N5AB-JF6L].

101 See Frank Sharry, Backlash, Big Stakes, and Bad Laws: How the Right Went for Broke and the Left Fought Back in the Fight over the 1996 Immigration Laws, 9 DrEXEL L. REV. 269, 287-88 (2017). 
President Obama's first term. ${ }^{102}$ Congress, however, never passed immigration reform.

For now, because of the limitations on the courts' review of immigration law and policies, political action is likely the only way to secure greater racial justice for immigrants. If successful, it can bring forth passage of the DREAM Act, comprehensive immigration reform, as well as reform of the immigration bureaucracy. To that end, newly elected President Biden may roll back the Trump Administration's immigration policies. ${ }^{103}$ However, if there is any hope for lasting and meaningful change, political action will need to continue to push for full justice for immigrants, rather than simply eliminating the Trump Administration's harsh policy initiatives. The aggressive immigration enforcement measures of the Obama Administration and failure to secure reform demonstrate that meaningful immigration change will not necessarily come from Democratic leadership in the White House. ${ }^{104}$

Building common ground between warring political factions will be necessary to bring about congressional action. ${ }^{105}$ Immigrant rights and antiimmigrant activists passionately advocate competing, and dramatically opposed, views about immigration and immigrants. Compromise on issues such as a path to legalization for undocumented immigrants, denigrated by opponents as an "amnesty" for lawbreakers, will be necessary for meaningful reform, but no doubt prove extremely difficult to achieve. ${ }^{106}$

The possibilities for transformation of the immigration laws through the political process are virtually limitless. A challenge for the immigrant rights movement will be to move beyond slogans such as "Abolish ICE" and figure out how to meaningfully transform and improve the entire U.S. immigration system, from the enforcement arm to the immigration courts to the rules for

${ }^{102}$ See Brian Bennett, U.S. Deported Record Number of Illegal Immigrants, L.A. TIMES (Oct. 6, 2010), http://articles.latimes.com/2010/oct/06/nation/la-na-illegal-immigration-20101007 [http://perma. cc/43PT-Z2CQ] ("Of the 392,862 deportations from October 2009 through September [2010], about half were illegal immigrants with criminal records. The total was about 3,000 more deportations than the record set in the previous year.").

${ }^{103}$ In its early days in 2021, the Biden Administration began to roll back numerous Trump immigration measures. See John Hudak \& Christine Stenglein, Biden's Immigration Reset, BRoOKINGS (Feb. 19, 2021), https://www.brookings.edu/blog/fixgov/2021/02/19/bidens-immigration-reset/ [https:// perma.cc/EF9Q-JMLW].

104 See Cházaro, supra note 84 (noting mass removals by Obama Administration).

${ }^{105}$ See generally Mariela Olivares, Resistance Strategies in the Immigrant Justice Movement, $39 \mathrm{~N}$. ILL. U. L. REV. 1 (2018) (examining contemporary immigrant resistance movements).

106 See David A. Martin, Taming Immigration, 36 GA. ST. U. L. REV. 971, 985-87 (2020). 
legal immigration. ${ }^{107}$ Although slogans can help organize, they cannot substitute for a concrete and specific agenda for transformative change. ${ }^{108}$ For example, even with some kind of path to legalization for undocumented immigrants, reform of the legal rules for immigration will be necessary if one wants lasting change that does not simply result in the emergence of a new population of undocumented immigrants, ${ }^{109}$ as occurred in the wake of previous legalization programs. Reform of the immigration court system, which has been the subject of sustained criticism for partisan bias and sheer ineptitude, ${ }^{110}$ is but another specific reform possibility.

Thus, one pressing task for immigrant rights activists in seeking to transform the immigration status quo in the United States will be offering a concrete change agenda. What kind of transformation is necessary and appropriate? Put differently, what is the positive immigration agenda? Answering these seemingly simple questions will be a formidable task in light of the many pressing and complex immigration issues facing the nation. Mere criticism of current immigration laws and policies may lead to incremental and piecemeal reform at the margins but not fundamental, meaningful, and truly transformational change. ${ }^{11}$

Because race is at the center of the consciousness of the immigrant community and a powerful rallying point for change, a successful movement for change necessarily must incorporate racial justice into any change agenda. Past resistance strategies "failed in part by not confronting the deep history of racism and discrimination against immigrants." 112

In sum, the immigrant rights movement will need to refine its goals and message and focus on a particular target or targets for change. That will be easier said than done as immigration is multifaceted, requiring many decisions about the necessary and appropriate changes and decisions about

107 For a call for alternatives to the modern immigration enforcement regime, see Peter L. Markowitz, After ICE: A New Humane \& Effective Immigration Enforcement Paradigm, 55 WAKE FOREST L. REV. 89 (2020).

108 See Shiu-Ming Cheer, Moving Toward Transformation: Abolitionist Reforms and the Immigrants, Rights Movement, 68 UCLA L. REV. DiscourSE 68, 71-77 (2020) (analyzing the distinction in the immigration reform movement between transformative abolitionist movements and incremental immigration reform).

109 See Martin, supra note 106, at 987-88.

110 See Mary Holper, The Fourth Amendment Implications of “U.S. Imitation Judges," 104 MinN. L. REV. 1275, 1276-77 (2020) (footnotes omitted) ("Scholars, immigration judges, attorneys, and congressional committees have been calling for a truly independent immigration adjudication system for decades, critiquing a system in which some judges describe themselves as 'U.S. imitation judges."').

111 See Daniel I. Morales, Dissent in Immigration, 16 L., CULTURE \& HuMANS. 250, 264-67 (2020) (encouraging immigration scholars to consider far-reaching changes to the contemporary immigration system).

112 Olivares, supra note 105 , at 7. 
what reforms warrant the highest priority. Differences among immigrant rights advocates exist on the necessary and essential law and policy changes. Nonetheless, building a racial justice coalition backing a set of positive immigration reforms will be an essential prerequisite for meaningful change.

Whatever the ultimate outcome of immigration politics, the future of the constitutional review of the immigration laws and The Chinese Exclusion Case rests in the hands of the Supreme Court. The outdated notion of limited or no constitutional review of the immigration laws was more appropriate for the nineteenth century when racial discrimination was legal ${ }^{113}$ than the twenty-first century when it is not. Despite the weighty interests of immigrants at stake, the Court remains locked into a system of constitutional review of the immigration laws more consistent with Jim Crow than the civil rights revolution.

Pro- and anti-immigrant activism has a long history in the United States. Anti-immigrant political movements often prevail in the political process. By engaging in limited, if any, constitutional review of immigration laws and policies generated by that process, ${ }^{114}$ the courts facilitated the success of such movements and the punishment of immigrants. The immunity of the immigration laws from constitutional review encourages Congress to act on its worst instincts and prevents any kind of meaningful dialogue between the judicial, legislative, and executive branches about the constitutional constraints on immigration law and policy. ${ }^{115}$ Although a revolution in rights over the twentieth century dramatically changed the constitutional landscape of the United States, immigration law has been mired in a legal backwater, with grudging expansion of the rights of immigrants. ${ }^{116}$

\section{CONCLUSION}

For now, immigration law and its enforcement are a deeply divisive political issue. Immigrant political action is constrained by the fact that immigrants cannot vote. However, immigrants now are exerting political pressure by taking to the streets and demanding change in no uncertain terms. ${ }^{117}$ Such activism, if sustained, may ultimately tip the balance in favor of meaningful immigration reform. For now, immigrant political activism shows no signs of fading away.

\footnotetext{
113 See Plessy v. Ferguson, 163 U.S. 537, 552 (1896) (upholding the racial segregation of African Americans), overruled by Brown v. Bd. of Educ., 347 U.S. 483, 495 (1954).

${ }^{114}$ See supra Part I.

115 See Hiroshi Motomura, The Curious Evolution of Immigration Law: Procedural Surrogates for Substantive Constitutional Rights, 92 CoLUM. L. REV. 1625, 1704 (1992).

116 See supra Part I.

117 See supra Part II.
} 
The nation, in all likelihood, will eventually see reform of the U.S. immigration laws. That reform will necessarily be the result of political action, not successful court cases. But the wait for reform could be many years, if not decades. Political activism will determine when that change is achieved.

In the end, only razing The Chinese Exclusion Case will make it possible to truly bring racial justice to immigration law. Meaningful constitutional review would discipline Congress and the Executive Branch in their treatment of immigrants in the immigration laws and their enforcement. True, the plenary power doctrine does not come into play in the ordinary immigration case, but it does constrain review of discriminatory-and often extreme-laws and enforcement measures that affect large numbers of immigrants, including laws and policies with glaringly disparate racial impacts. Without constitutional constraints, the nation can expect repeated episodes of anti-immigrant sentiment fueled by racial animus, with the Trump presidency simply marking the most recent and extreme one. 